\title{
Physics bears the brunt of research council's accountability demands
}

London. British physicists are up in arms over a plan by the Engineering and Physical Sciences Research Council (EPSRC), one of the principal sources of support for research in UK universities, to cut their funding two years from now by almost four per cent below its currently projected level.

In contrast, the EPSRC has also provisionally decided to increase funding in the same financial year for both chemistry and mathematics by 5.2 per cent. But marine technology and the 'built environment' have, like physics, both been selected for a cut, in each case by 4.8 per cent.

The proposed redistribution in 1988-89 of the $£ 375$ million that the council allocates every year to British researchers - the figures could still be revised before a final decision is reached - represents an explicit attempt to reshuffle funding priorities between different fields of science, taking into account both scientific quality and potential contribution to wealth creation.

EPSRC officials say that the decision to cut the physics budget is intended to send a signal to physicists that, in contrast to chemists and mathematicians, they do not seem to be generating enough innovative ideas, or building enough links with industry, to justify their current funding level.

"This is not a plea to physicists to become more applied," insists Richard Brook, chief executive of the EPSRC, and previously a professor of materials science at the University of Oxford. "We are hoping that physicists will come back with some basic physics proposals that look exciting; if they can do this, then the figures will be changed."

But physicists reject the charge that their field has become static. They claim in reply that the council's move reflects a lack of understanding of the way that physics, in contrast to fields such as chemistry, contributes to wealth creation not through a specific industry but by underpinning developments across a range of industries.

"We are disappointed at the EPSRC's decision," says Alun Jones, chief executive of the Institute of Physics (IOP). He says that the institute is already preparing detailed evidence of the contribution of physics to British industry, and plans to ask its own committees to identify "burgeoning areas" of the subject, to be used to refute the charge that the subject is becoming stale.

The pressures facing British physicists have some of their origins in the government's decision to split the former Science and Engineering Research Council (SERC) in its white paper of May 1993. As a result of this split, much of SERC's more fundamental research has now been hived off into the new Particle Physics and Astronomy Research Council (PPARC).

EPSRC, which took on most of SERC's remaining activities, retains responsibility for both basic and applied research. But it also has a more explicit mission than PPARC to ensure that the research it funds contributes to national wealth creation (and to enhancing the quality of life).

In line with this new mission, the success of individual scientific disciplines in building links to industry was high among 17 explicit criteria used by EPSRC's new Technical Opportunities Panel - known as TOP, and made up of leading researchers from universities, industry and elsewhere - in preparing recommendations to the full council on how the distribution of research finds in 1998-99 should be adjusted from merely a neutral extension of current funding trends (see next page).

The council, acting largely on the recommendations of TOP, has now suggested increased funding for some areas of obvious application; for example, it proposes that support for research into control and instru- mentation technologies be increased by 5.2 per cent, and for information technology by 2.8 per cent.

But EPSRC officials point out that - as the proposed cutback in marine technology illustrates - a field's potential contribution to wealth creation is not sufficient to protect its research budget. Conversely, they say, disciplines such as mathematics which have demonstrated both an intellectual vitality and a commitment to closer industrial linkages should be rewarded with the prospect of increased funding.

Thus the council's proposed 3.8 per cent cut in the physics programme, with the implicit threat that the cut could be even deeper if physicists do not pull their socks up, is defended as a deliberate judgement on the current state of those aspects of the discipline - such as solid-state physics and nuclear structure - that have not been taken on by PPARC.

"Many physicists seem to be ignoring the result of the Technology Foresight exercise, and to lack any great interaction with industry," says Brook. He points out, for example, that physicists have done relatively badly compared to those from other

\section{Einstein paper on the path to riches}

Washington. Who says basic physics does not make money (see above)? A 1912 manuscript by Albert Einstein on relativity theory - the longest and earliest known manuscript on the subject penned by Einstein himself - will be auctioned in New York next month. Sotheby's, which is handling the sale planned for 16 March, expects the 72-page document to fetch between $\$ 4$ million and \$6 million, placing it among the most valuable manuscripts ever sold.

Written for an unpublished scientific text commissioned by the German publisher Akademische Verlagsgesellschaft, the document's existence was unknown until 1987, when heirs of the publisher sold it for $\$ \mathbf{1 . 2}$ million to the current owner, an anonymous collector.

Einstein made no effort to preserve his own papers before the $1920 \mathrm{~s}$, making this document - written between his development of the special theory of relativity in 1905 and the general theory in 1916 - all the rarer. All but one of the handful of early Einstein papers previously known to exist, the exception being a short paper written

\section{IMAGE UNAVAILABLE FOR COPYRIGHT REASONS}

Pride of place: a float representing Albert Einstein in last week's carnival in Rio de Janeiro.

when the scientist was 16 years old, are in public collections in Israel and elsewhere.

Although the edited text of the manuscript being auctioned next month has appeared in print, in a multi-volume set of Einstein papers published by Princeton University last year, the handwritten version contains extensive revisions and deletions that give clues to Einstein's thinking during one of his most creative periods as a scientist, according to David Redden, a senior vice president at Sotheby's. Tony Reichhardt 
disciplines in applications for the so-called ROPAs awards - named after the white paper Realising our Potential, and aimed explicitly at rewarding those with a record of successful collaboration with industry.

Some directly involved in the council's decision claim that physicists have failed adequately to 'sell' the value of their work to the new council. "Looking at the general message behind the decision, I feel that physicists need to do more to get across the idea that their work contributes to new developments in many other disciplines," says Laurie Challis, professor of physics at the University of Nottingham, and himself a

\section{CRITERIA USED BY EPSRC TO EVALUATE} SCIENTIFIC PROGRAMMES

Potential SOCIO-EConomic Benefits

1. Economic Competitiveness

2. Provision of Basic Needs

3. Physical Security and Safety

4. Health Improvement

5. Skills Requirements

NATURE OF RESEARCH

6. Alignment to Foresight

7. Research Potential

8. Pervasiveness

9. Interdisciplinarity

ABILITY TO CAPTURE BENEFITS

10. Strength of User Community

11. Uptake Capacity of User Community

12. Potential for Rapid Technology Transfer

PROVIDER CAPABILITY

13. Strength of Provider Base

14. State of Provider Base

FUNDING CONSIDERATIONS

15.Importance of EPSRC Funding

16. Funding Leverage Potential

17. Capacity to Absorb Increase in Funding

member of the TOPS panel. "This is certainly a glitch, but it may be a useful one."

Others are less charitable, suggesting that the potential value of physics to wealth creation had been misrepresented during the council's deliberations, and criticizing the council for not consulting even those physicists involved in reviewing EPSRC grants applications in reaching its decision. "This was a decision that was reached in some haste behind closed doors," says JeanPatrick Connerade, professor of physics at Imperial College London.

Jones at the IOP rebuts the implications that physicists are resting on their past achievements, and that an ageing population is reluctant to give way to younger researchers with new ideas. "There is no evidence that physics is anything but exciting," he says, while underlining the institute's keenness to help the EPSRC to identify where physics should grow. "We have said that we will do our best, because if we do not do it, who will?" he says.

But Brook has few apologies for the council's decision. "We have to have an effective mechanism for ensuring that taxpayers get value for the money spent on research," he says. "We are trying to buy the best research we can with the money we have available."

David Dickson

\section{Researchers 'duped' over use of embryos without consent}

San Diego. The debate surrounding infertility research at the University of California at San Diego (UCSD) has taken a new twist with evidence that viable human eggs and embryos taken from patients without their consent have been unknowingly used by a research team at the University of Wisconsin.

This was revealed in an audit by the university, completed late last month, of the activities of Ricardo H. Asch, who operated infertility clinics at UCSD and the University of California at Irvine (UCI) before fleeing the country last year while under investigation for alleged misappropriation of embryos and financial offences (see Nature 376, 456; 1995).

Asch's research conduct is also under investigation at UCI and Cornell University in Ithaca, New York. Officials from UCI, Cornell and the federal Office for Protection from Research Risks are investigating the transfer of embryos from Irvine to Cornell for experimental chromosome testing.

During the UCSD investigation, auditors from KPMG Peat Marwick found that Asch had in 1994 provided about 450 egg or embryo specimens to a researcher at Wisconsin, Gerald Schatten, without the consent of their donors. Auditors found that at least 21 of the inseminated eggs and 3 embryos were viable. (The remaining eggs and embryos were from failed fertilization procedures, officials said, and would therefore have been discarded as defective.)

Officials at UCSD and Wisconsin say they have no evidence that Shatten was aware that the material sent to him by Asch lacked informed consent. Indeed, records uncovered during the audit indicate that Schatten appears to have been deliberately misled by Asch.

According to Shatten, Asch had provided him with written assurance that the UCSD Human Subjects Committee had approved the use of the eggs and embryos. Schatten has so far declined to comment on the audit's conclusions, citing potential legal action against Wisconsin.

Norman C. Fost, chairman of Wisconsin's Institutional Review Board, says that the university required Schatten to ensure that Asch had obtained informed consent from patients. "We didn't know Asch wasn't telling the truth," says Fost. "We can't hold our researchers to be policemen of researchers at other institutions."

Asch, a native of Argentina, has been living in Mexico City since September after fleeing a federal criminal investigation and at least 18 civil lawsuits. He was not available for comment, and his California attorneys say he is not responsible for the alleged lapse of research review procedures, blaming university officials for any paperwork mix-ups.

UCSD cancelled Asch's clinical faculty appointment last June, and closed its assisted reproductive technology clinic after the initial allegations. Its subsequent audit has reminded US universities of the sensitivities surrounding research in human reproduction; the National Institutes of Health, for example, have declined to fund human embryo research, because, it is widely believed, of fear of a political backlash.

The UCSD auditors found that Asch had operated his infertility clinic with little administrative supervision, and that there were inadequate written policies to control such operations. Also, the procedures that did exist failed to uncover the alleged irregularities until they were first disclosed by the press last spring.

Both UCSD and Wisconsin officials say that, because of his international reputation as a leading infertility specialist, they relied upon Asch to conduct himself properly. "The affair forces a researcher to question everyone," says one Wisconsin official privately. "This has shaken the entire reproductive medicine field. It will be years until it recovers. It is a shame, because a lot of good science was being done."

Thomas R. Moore, acting chief of reproductive medicine at UCSD, says university authorities "were concerned and dismayed" last year during the early phases of the investigation when they found Asch was using discarded tissue without consent. But these feelings have turned to shock with the recent discoveries. "If indeed this occurred, this is a blatant breach of established policies and procedures as well as an ethical outrage," says Moore.

The UCSD scrutiny of Asch also uncovered another project being conducted without a university-approved protocol. This involved follicular fluid and ovarian tissue from Asch's women patients being given to a university laboratory for unapproved biological and molecular research.

The reproductive medicine researcher conducting these studies, Gregory F. Erickson, was placed on probation for a year, with university officials now monitoring his projects more closely. UCSD officials are also investigating the role of two fellows associated with the project.

"It was an honest mistake to fail to realize I didn't have a protocol in place," says Erickson, who points out his 20 -year career at UCSD was previously unmarred. "I am sorry it happened. The university did the right thing by putting me on probation."

Rex Dalton 